\title{
Narracyjna złożoność współczesnego serialu telewizyjnego na przykładzie Breaking Bad Vince’a Gilligana
}

vol. XVI/no. 25

Poznań 2015

ISSN 1731-450X

Nie ulega wątpliwości, iż na przełomie kilku ostatnich lat serial telewizyjny przeżywa swój kolejny wielki renesans, i to w zupełnie innej niż produkcje doby końca XX wieku formule. Mówi się, że doświadczamy aktualnie trzeciej złotej ery telewizji - za pierwszą uważa się lata 50., a druga przypada na okres między wczesnymi latami 80. a środkiem lat 9o. (jak twierdzi Robert J. Thompson - autor książki na temat drugiej złotej ery amerykańskiej telewizji - od Posterunku przy Hill Street do Ostrego Dyżuru[1]). Sam jednak Thompson przyznaje, że jego kompendium dobrych seriali drugiej ery jest stosunkowo krótkie, bo nie było wówczas zbyt wielu produkcji, o których mógłby pisać. Dziś, jak sam twierdzi, „wiele się jednak zmieniło”[2]. Obecnie mówi się o telewizji ery postsieci (post-network era) charakteryzującej się wielokanałowością oraz zwrotem z nadawania programów dla masowego odbiorcy (broadcasting) ku kierowaniu ich do zawężonego grona widzów (narrowcasting). Na istotne zmiany aktualnego kształtu telewizji zwraca także uwagę Amanda Lotz, wprowadzając pojęcie telewizji zjawiskowej (phenomenal television), której oferta programowa cechuje się niespójnością „tematów, zagadnień i dyskursów” w nią włączonych oraz ich „wartościami artystycznymi i znaczeniem społecznym”, czyli „kapitałem kulturowym”[3]. Nie sposób również pominąć tak bardzo popularnego w obecnej refleksji medioznawczej, choć wciąż niejednoznacznego i wzbudzającego skrajne opinie pojęcia jak telewizja jakościowa (quality television), której synonimem stała się stacja HBO, konsekwentnie odżegnująca się od utożsamiania jej z "tradycyjnym” i poniekąd stereotypowym wyobrażeniem telewizji. Z grubsza rzecz ujmując, programy nadawane przez quality television określane są jako bardziej „wartościowe” pod względem ich „treści, struktury, tematyki i wydźwięku” [4]. Jak tłumaczy Sarah Cardwell:

Programy amerykańskiej jakościowej telewizji z reguły są dobrze zrealizowane, charakteryzują je: naturalistyczna gra aktorska, obecność

[1] R.J. Thompson, Television's Second Golden Age: From „Hill Street Blues” to „ER”, New York 1996.

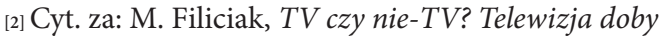
post-soap i sieci peer-to-peer, w: Post-soap. Nowa generacja seriali telewizyjnych a polska widownia, red. M. Filiciak i B. Giza, Warszawa 2011, s. 240.

[3] A. Lotz, Zrozumieć telewizję u progu postsieci [post-network era], przeł. M. Poks, w: Zmierzch telewi- zji? Przemiany medium. Antologia, wyb. i red. T. Bielak, M. Filiciak, G. Ptaszek, Warszawa 2011, s. 96-103. [4] S. Cardwell, Czy telewizja jakościowa jest dobra? Różnice gatunkowe, oceny oraz kłopotliwa kwestiakrytycznego osądu, przeł. D. Kuźma, w: Zmierzch telewizji? Przemiany medium. Antologia, op. cit., s. 137. 
znanych i szanowanych aktorów, wyczucie wizualne, kreowane przez staranną, czasem nowatorską pracę kamery i montaż, oraz stylowa ścieżka dźwiękowa, [...] [a także - przyp. Z.L.] poczucie spójności stylistycznej, w której motywy i styl przeplatają się w ekspresywny i robiący wrażenie sposób[5].

Dynamiczne zmiany, jakim od mniej więcej dwóch dekad poddawana jest telewizja, najbardziej wyraziście odbiły się zatem na konstrukcji i tematyce seriali z ostatnich kilku lat. Cezura wydaje się problematyczna, jednak większość krytyków i filmoznawców zgodnie twierdzi, że pierwszą jaskółką zwiastującą ów charakterystyczny zwrot w sposobie kreowania serialowej fabuły było Miasteczko Twin Peaks (Twin Peaks, 1990-1991) Davida Lyncha, który z powodzeniem przeniósł na szklany ekran schematy kina artystycznego, łącząc je z konstytutywnymi dla struktury serialu wyznacznikami. Przełomowy stał się już jednak z pewnością serial produkcji HBO Rodzina Soprano (The Sopranos, 1999-2007), który Jane Feuer nazywa dramatem jakościowym (quality drama) zawierającym w sobie „oczywiste elementy narracji seryjnej” i „odwołującym się do innych niż telewizja mediów”[6]. Jak słusznie zauważa Mirosław Filiciak, produkcja ta w istotny sposób przyczyniła się do tego, iż obecnie ,jesteśmy świadkami prawdziwego zalewu seriali eksperymentujących z tradycyjną formułą, łamiących konwencje i równocześnie stawiających odbiorcom spore wymagania, czasem na granicy trudności zrozumienia powiązań między spiętrzonymi wątkami”[7]. Seriale tego pokroju - wykorzystujące przede wszystkim dwuznacznego moralnie bohatera - autor określa mianem „post-soap”. Z jednej strony są „formami seryjnymi alinearnymi”, a z drugiej „mają zupełnie inny status kulturowy, [ponieważ - przyp. Z.L.] są najczęściej pozbawione wątków melodramatycznych i zaskakująco odważne obyczajowo" [8].

Swą funkcjonalność zdaje się również tracić klasyczne rozróżnienie na serię i serial, gdzie seria oparta jest na odcinkach tworzących zamkniętą całość - akcja zamyka się w jednym epizodzie, a fabuła ma swój określony początek, rozwinięcie i koniec - a serial to ciąg odcinków (z których każdy zazwyczaj kończy się cliffhangerem - zawieszeniem akcji w kulminacyjnym momencie na zasadzie „ciąg dalszy nastąpi”) składających się na jedną, niepodzielną całość fabularną. Obecnie mamy do czynienia z czymś w rodzaju hybrydy - w toku jednego sezonu (lub nawet kilku) rozwijana jest jedna konkretna linia fabularna (jak w przypadku serialu Dexter [Dexter, 2006-2013] - w każdym poszczególnym sezonie bohater zmaga się z monstrum większego kalibru,

[5] Ibidem.

[6] J. Feuer, HBO i pojęcie telewizji jakościowej, przeł. M. Filiciak i inni, w: Zmierzch telewizji? Przemiany medium. Antologia, op. cit., s. 119.

[7] M. Filiciak, op. cit., s. 243.

[8] Ibidem, s. 239. Autor - jako wzorcowe przykłady tego typu seriali - przywołuje tu m.in. takie produk- cje jak Prawo Ulicy (2002-2008), Trawka (2005-2012) czy Sześć stóp pod ziemią (2001-2005). W tę definicję z pewnością wpisuje się wiele popularnych współczesnych seriali, wymieniając chociażby Dextera (2006-2013), Dr. House'a (2004-2012), Grę o tron (2011-), Synów anarchii (2008-2014), Hannibala (2013-). 
a na przestrzeni wszystkich sezonów rozwija swoje relacje $\mathrm{z}$ innymi postaciami, a także zmaga się ze swoją przeszłością, dojrzewa, zmienia się etc.), natomiast w obrębie określonego epizodu wprowadzana i finalizowana jest jedna historia (w poszczególnym odcinku Dexter rozwiązuje jedną zagadkę lub toczy walkę $\mathrm{z}$ „potworem tygodnia”). Serial kontynuowany - jakim to mianem Arkadiusz Lewicki określa produkcje, w których rozwijana jest jedna opowieść - wydaje się obecnie jednym $\mathrm{z}$ najbardziej eksploatowanych formatów [9]. Znamienna dla seryjności reguła różnicy i powtórzenia, choć nadal obecna, również zdaje się tracić swą wyrazistość - powtarzające się pod naporem powracających konfliktów i kryzysów sytuacje budują bowiem treść naddaną i mimo wszystko zmierzają do konkretnego celu, czyli finalnego rozwikłania historii.

Jak twierdzi Jason Mittell:

[...] w ciągu ostatnich dwóch dekad pojawił się nowy paradygmat telewizyjnego opowiadania, który spowodował przesunięcie granicy między formami odcinkową i serialową, rozwinął wysoki poziom samoświadomości w kwestii mechanizmów opowiadania oraz zapotrzebowanie na zwiększone zaangażowanie widza skupiającego się zarówno na diegetycznych przyjemnościach, jak i świadomości formalnej[10].

Seriali wpisujących się w ów paradygmat, czyli wykorzystujących innowacyjne techniki narracyjne i rozwiązania formalne, jest na obecnym rynku telewizyjnym coraz więcej - poczynając od sfinalizowanych serii Sześciu stóp pod ziemią (Six Feet Under, 2001-2005) czy Zagubionych (Lost, 2004-2010), a kończąc na wciąż pojawiających się sezonach Gry o tron (Game of Thrones, 2011-) lub Detektywa (True Detective, 2014-). Na szczególną uwagę w kontekście znamiennych dla telewizji jakościowej przekształceń formalnych i treściowych zasługuje jeden z najbardziej nośnych i popularnych seriali ostatnich lat, czyli Breaking $\mathrm{Bad}$, nadawany przez stację AMC w latach 2008-2013. Stworzony przez koproducenta i współscenarzystę kilku serii $Z$ archiwum $X$ Vince’a Gilligana, tylko pozornie bazuje na tradycyjnym schemacie „od zera do milionera”, a raczej - jak ujął to sam twórca - „od Mr. Chipsa do Scarface'a”. Fabuła skupia w sobie wiele komplementarnych wątków, które jednak oscylują wokół postaci głównego bohatera i jego stopniowej ewolucji. Wielopoziomowa struktura dramaturgiczna i złożoność narracyjna dzieła Gilligana skłaniają ku bliższemu przyjrzeniu się aspektom, które czynią go reprezentatywnym dla nowej fali produkcji telewizyjnych.

Serial przedstawia historię Waltera White’a - nauczyciela chemii przeciętnego amerykańskiego liceum i niespełnionego życiowo

[9] Por. A. Lewicki, Kino i telewizyjne seriale $w$ epoce konwergencji mediów, w: idem, Od House'a do Shreka. Seryjność w kulturze popularnej, Wrocław 2011, s. 34.
[10] J. Mittell, Złożoność narracyjna we współczesnej telewizji amerykańskiej, przeł. D. Kuźma, w: Zmierzch telewizji? Przemiany medium. Antologia, op. cit., s. 176 . 
frustrata, który w obliczu nieuleczalnej choroby, jaka spada na niego niczym grom $\mathrm{z}$ jasnego nieba, postanawia zaangażować się w produkcję (generującej ogromne zyski w USA) metamfetaminy celem zapewnienia swojej rodzinie finansowego zabezpieczenia, gdy on odejdzie już z tego świata. Aby przedsięwzięcie się powiodło, znajduje sobie partnera w osobie jego dawnego ucznia Jessego Pinkmana, który jak się okazuje - od dłuższego już czasu para się "gotowaniem mety”. Początkowo niedostosowany do nowych sytuacji związanych z problemami, jakie napotykają w związku z produkowaniem i dystrybucją narkotyku, Walter coraz silniej zaczyna wnikać w przestępczy światek i (po części nieświadomie) odkrywa swoje drugie, mroczne ja. Główny wątek opiera się zatem na stopniowym zatracaniu się bohatera w życiu poza prawem, przechodzeniu na „złą stronę" i jego ewolucji w kierunku swoistego „jądra ciemności”, czyli na tytułowym breaking bad[11]. Im mocniej angażuje się w działalność narkotykową, tym bardziej musi ukrywać swą drugą twarz przed rodziną, która niczego się nie domyśla. Równolegle rozwijają się także jego stosunki z Jessem, upodabniające się do relacji między ojcem a synem, balansującej na skrajnych uczuciach przyjaźni i wrogości. Wraz z postępującą akcją bohater musi się również zmagać $\mathrm{z}$ antagonistami coraz to większego kalibru - od osiedlowego dilera Krazy-8, przez wyżej postawionego w hierarchii dystrybutora Tuco, aż po magnata imperium narkotykowego Gustavo Fringa. Pod koniec stawia również czoła swojemu szwagrowi Hankowi, który jako agent DEA (Drug Enforcement Administration - amerykańska agencja rządowa ds. walki z narkotykami) od samego początku serialu ściga Heisenberga (pseudonim głównego bohatera), nie wiedząc, że jest nim Walter. Całej fabule towarzyszy oczywiście wiele wątków pobocznych, takich jak miłosne uniesienia Jessego czy też romans żony Waltera Skyler z jej szefem. Tłem dla historii jest walka głównego bohatera $\mathrm{z}$ rakiem, która raz odchodzi na dalszy plan, a raz ponownie zostaje włączona w przebieg akcji celem uwypuklenia widma śmierci ciążącego nad Walterem i przypomnienia widzom jego pierwotnych pobudek.

W przypadku Breaking Bad mamy do czynienia z serialem kontynuowanym, którego ani poszczególne odcinki nie mogą funkcjonować jako osobne i zamknięte struktury, ani nawet same sezony, jako że historia budowana jest w oparciu o wszystkie epizody serii. Przejścia między poszczególnymi sezonami są płynne i pozbawione elips - i tak sezon drugi zaczyna się sceną identyczną jak ta, która kończyła sezon pierwszy (podobnie rzecz ma się z sezonem piątym i czwartym), a wydarzenia z początku zarówno trzeciego, jak i czwartego sezonu (następujące po silnych cliffhangerach - w przypadku drugiego sezonu jest to katastrofa lotnicza tuż nad domem Waltera, a trzeciego - zabójstwo

[11] Zwrot to break bad jest charakterystyczny dla południowo-zachodnich rejonów USA i oznacza „podejmowanie działań na granicy prawa, stawianie czoła konwencjom i kontestację autorytetów”. Źródło:
Jake Jawesome, Break Bad, http://www.urbandictionary.com/define.php?term=Break\%2oBad [dostęp: 05.11.2014]. Tłumaczenie $\mathrm{z}$ języka angielskiego mojego autorstwa. 
ekspomocnika Waltera Gale’a dokonane przez Jessego) ruszają z tego samego miejsca, na którym zatrzymała się akcja z finalnych scen poprzedzających je sezonów. Aby zatem w pełni prześledzić i zrozumieć historię, widz musi chronologicznie obejrzeć wszystkie sezony, gdyż pominięcie któregokolwiek epizodu sprawi, iż nie będzie on w stanie wypełnić wszystkich luk w strukturze przyczynowo-skutkowej fabuły, a także pozbawi go istotnej wiedzy na temat zarówno minionych, jak i przyszłych wydarzeń.

Konstrukcja serialu i jego przebieg fabularny z jednej strony wpisują się w postępowanie seryjne, opisywane przez Jürgena Trinksa jako oparte na „stabilnych okolicznościach, które zostają przełamane pod naporem powtarzających się kryzysów lub pojawiających się nowych zdarzeń", a z drugiej zrywają z jego głównymi cechami, wśród których badacz wyszczególnia „wymienialność i różnorodne możliwości łączenia występujących w seriach sytuacji, osób, konfliktów etc. oraz związaną z tym możliwość rozwijania się w nieskończoność pewnej historii, która ani przez ustrukturowanie, ani przez usensowienie nie jest zorientowana na żaden określony koniec" [12]. Wraz z postępującą akcją do fabuły wprowadzane są coraz to nowsze przeciwności, z którymi Walter musi się zmagać - czy to w postaci antagonistów (z którymi bohater zazwyczaj początkowo zawiera sojusz), czy okoliczności, jak np. przejęcie przez policję laptopa $\mathrm{z}$ materiałem dowodowym $\mathrm{z}$ laboratorium Waltera bądź trudności z uruchomieniem stojącego na środku pustyni kampera służącego bohaterom jako miejsce do "gotowania”. Problemy, jakie napotyka Walter, są przez niego tylko pozornie rozwiązywane - potęgują one lub nawarstwiają inne komplikacje, przez co świat nigdy nie powraca do harmonii czy też do pierwotnego porządku, wciąż trzymając widza w napięciu. Wydarzenia, jakie mają miejsce w serialu, przekształcają zatem zastaną rzeczywistość w zupełnie inny stan - wszystkie napotykane przez Waltera konfliktowe sytuacje lub problemy prowadzą do coraz to bardziej skomplikowanych położeń i niebezpiecznych zdarzeń, z których właściwie nie ma już wyjścia na zasadzie „powrotu do stanu poprzedniego” - może on tylko brnąć dalej w głąb ,jądra ciemności”. Wprowadzanie tego typu rozwiązań osłabia zatem zasadę seryjności charakterystyczną dla serialu jako takiego, zbliżając konstrukcję Breaking Bad do - typowej dla powieści (bądź filmu) - reguły narratywności, którą Trinks definiuje w następujący sposób: „[...] w obrębie już istniejącego, stabilnego i łatwo uchwytnego empirycznie stanu - pojawia się nowy, wyraźnie różniący się od niego moment, co prowadzi do przekształcenia się w inny stan, znoszący stan poprzedni”"[13]. Co więcej, serial ten (w przeciwieństwie do klasycznych serii) poprzez swą wyraźnie zarysowaną linię fabularną oraz logiczną spójność konstrukcyjną i przyczynowo-skutkową jest wyraźnie zorientowany na określony koniec.

[12] J. Trinks, Seryjność jako podstawowy problem estetyki telewizji, przeł. F. Chmielowski, w: Piękno w sieci.
Estetyka a nowe media, red. K. Wilkoszewska, Kraków 1999, s. 166.

[13] Ibidem. 
Budowa dramaturgiczna Breaking Bad wpisuje się zatem w coraz bardziej popularny w amerykańskich serialach doby telewizji jakościowej trend, który Jason Mittell określa jako złożoność narracyjną (narrative complexity), definiując go w następujący sposób:

Złożoność telewizyjnej narracji opiera się na konkretnych aspektach samej opowieści, dopasowanych do specyficznej struktury serialu, która odróżnia telewizję od filmu i wyodrębnia ją z klasycznych odcinkowych i seryjnych form. [...] polega ona na przedefiniowaniu form epizodycznych pod wpływem narracji seryjnej - niekoniecznie na całkowitym ich połączeniu, lecz na przeniesieniu środka ciężkości. Odrzucając wymóg fabuły zamkniętej w obrębie pojedynczego odcinka, co cechuje konwencjonalne formy epizodyczne, złożoność narracyjna wysuwa na pierwszy plan opowieści snute z wykorzystaniem różnych gatunków[14].

W ramach złożoności narracyjnej serialu Breaking Bad wyszczególnić można kilka charakterystycznych dla jego konstrukcji zabiegów (które Mittell określa mianem złożonych i niekonwencjonalnych) - zarówno w warstwie formalnej, jak i treściowej. W pierwszej kolejności należałoby przyjrzeć się chwytom typowo dramaturgicznym, jakimi są: retrospekcja (flashback), futurospekcja (flashforward) i tzw. cold open - sekwencja wprowadzana przed samą czołówką serialu, często utożsamiana z teaserem. Każdy z odcinków serii - przed właściwym rozpoczęciem - poprzedzony jest bowiem sceną, która: 1) kontynuuje akcję z poprzedniego epizodu, 2) wprowadza zupełnie nowy wątek, np. historii rozgrywającej się paralelnie do wiodących wydarzeń (zainicjowanie intrygi związanej z pojawieniem się kuzynów Tuco w trzecim sezonie - odcinek No Mas [So3Eo1]), 3) stanowi futurospekcję - zapowiedź przyszłych wydarzeń (w pilocie serialu pojawia się jego ostatnia scena, a w środkowym epizodzie sezonu piątego cold open stanowi scena z samego końca serii) lub 4) przyjmuje kształt retrospekcji, czyli przywołuje minione wydarzenia (na początku odcinka Mas [SozEo5] przedstawiona zostaje historia nabycia kampera, a w odcinku I.F.T. [So3Eo3] scena zabicia Tortugi). Cold opens służą zatem nie tylko wprowadzeniu widzów w ciąg dalszy fabuły czy też zapoznaniu ich z nowymi wątkami, lecz także zaintrygowaniu ich poprzez pokazanie przyszłych wydarzeń (odbiorca zastanawia się więc, jak i kiedy do nich dojdzie) lub wyjaśnieniu bądź doprecyzowaniu wcześniejszych sytuacji poprzez wypełnienie luk narracyjnych, aby dalsza historia stała się dla widzów bardziej logiczna i zrozumiała. Celem uatrakcyjnienia serialu od strony formalnej twórcy wprowadzają także jako cold opens sceny-teledyski, jak np. w odcinku Negro y Azul (So2E07) introdukcję stanowiła wstawka muzyczna grupy mariachi śpiewających o Heisenbergu i „nowym, niebieskim towarze" na rynku.

Na szczególną uwagę zasługują futurospekcje stanowiące zajawki punktu kulminacyjnego, wprowadzane po to, by cofnąć się do początku i wyjaśnić, co doprowadziło do przedstawionych w nich wydarzeń. Cold

[14] J. Mittell, op. cit., s. 152-159. 
open pilota wygląda w następujący sposób - ubrany jedynie w bieliznę i maskę gazową Walter pędzi przez pustynię kamperem, w którym przetaczają się nieruchome ciała, a następnie zatrzymuje się i wysiada z pojazdu. W tle słychać głos policyjnych syren, więc zrozpaczony bohater szybko zabiera część swoich osobistych rzeczy oraz broń od jednego z półżywych delikwentów i przenośną kamerą nagrywa rodzaj filmu pożegnalnego dla rodziny, po czym, dzierżąc w ręku pistolet, wychodzi na drogę. Akcja serialu zaczyna się zatem in medias res - w środku wydarzeń, o których widz nie ma pojęcia. Dopiero wraz z przebiegiem akcji całego odcinka dowiaduje się, kim jest bohater, dlaczego ucieka i skąd wzięły się ciała. Elementem zaskoczenia staje się również fakt, że - odwrotnie niż można by wnioskować z wprowadzonej przed czołówką sceny - Walter wcale nie jest w tak wielkich tarapatach, jako że - jak się okazuje - odgłosy syren nie należały do policji, a do straży pożarnej. Najciekawszy rodzaj futurospekcji pojawia się na przestrzeni całego sezonu drugiego - jest to jeden wielki flashforward stopniowany w cold opens poszczególnych odcinków. Wpierw widz ma do czynienia $\mathrm{z}$ detalem - obrazem różowego misia pływającego w basenie, po czym $\mathrm{z}$ każdą sceną poprzedzającą napisy perspektywa stopniowo poszerza się - wpierw o plan półpełny zdewastowanego patio rodziny Whiteów, po którym chodzą ubrani w białe kostiumy technicy, aż po plan pełny ich zniszczonego domu. W utrzymaną w kolorystyce szarości całość (jedynym barwnym elementem jest wspomniany wyżej różowy miś) wkomponowane są zbliżenia przedstawiające techników zbierających dowody. $Z$ wydarzeń, które mają miejsce na przestrzeni kolejnych epizodów (coraz większe problemy bohatera, komplikacje związane z dystrybucją narkotyków), widz wnioskuje, że futurospekcje te przedstawiają czarną przyszłość Waltera, czyli np. możliwy atak coraz groźniejszego kartelu. Jak się jednak okazuje w ostatnim epizodzie sezonu, wszystkie sceny z cold opens, składające się tak naprawdę na jedną sekwencję, odnoszą się do katastrofy lotniczej, która miała miejsce nad domem Waltera, a do której on sam pośrednio się przyczynił.

W odróżnieniu od futurospekcji retrospekcje nie tylko pojawiają się jako cold opens - są one także wprowadzane w toku całych odcinków. $\mathrm{W}$ formie wprowadzenia do epizodu są introdukowane jako obiektywne i stanowią część właściwej diegezy filmowej - doprecyzowują przeszłe wydarzenia i jako sjużet wypełniają luki fabularne, które domagają się wyjaśnienia, aby nadchodzące sytuacje zyskały swój pełny sens i logikę. Dla przykładu w odcinku One Minute (SozEo7) przywołana zostaje scena $\mathrm{z}$ dzieciństwa kuzynów Tuco, z której widz dowiaduje się, że więzy rodzinne są dla członków kartelu najważniejsze - tłumaczy więc ona ich niepohamowaną żądzę zemsty na Walterze za zdradę Tuco. Natomiast na początku epizodu Mas (So3E05) wprowadzona zostaje historia zdobycia kampera (Jesse kupuje go od przyjaciela, który znany jest później policji jako zamordowany przez konkurencyjny gang diler) stąd w dalszej części serialu widz wie, że koniec końców Hank dotrze do źródła, z którego wziął się pojazd i Jesse będzie miał z tego powodu 
problemy. Retrospekcje przyjmują również wymiar subiektywny - zbierając resztki ciała zamordowanego dilera Emilia, Walter przypomina sobie rozmowę z byłą dziewczyną na temat pierwiastków, z których składa się ludzkie ciało (...And the Bag's in the River, So1Eo3). Z tego typu zsubiektywizowanymi reminiscencjami mamy również do czynienia w toku akcji danego epizodu - w odcinku Felina (So5E16) Walter, patrząc na swój opustoszały i zniszczony dom, przywołuje w pamięci obraz sprzed dwóch lat, kiedy spędzał tam urodziny i po raz pierwszy usłyszał o tym, ile można zarobić na produkcji metamfetaminy. Wszystkie tego typu rozwiązania są bardzo charakterystyczne dla narracyjnie złożonych seriali - jak pisze Mittell:

[...] brak wyraźnych podpowiedzi i wskazówek wytwarza chwile dezorientacji, zachęcając widza do głębszego zaangażowania w zrozumienie fabuły [...]. Złożone narracyjnie programy chętnie wykorzystują chwilową dezorientację i zagubienie widzów, pozwalając im doskonalić swoje zdolności przyswajania przez długoterminową przygodę z serialem oraz aktywne w nim uczestnictwo[15].

Złożoność narracyjna Breaking Bad realizuje się również na wyższym poziomie. Serial można bowiem określić dramatem następstw, jako że wszystko, co pojawia się zarówno w warstwie wizualnej (w szczególności detale), jak i fabularnej (rozmowy i działania bohaterów), ma swoje późniejsze uzasadnienie. Elementy pojawiające się w diegezie filmowej mają jednocześnie znaczenie symboliczne (jak np. mucha odczytywana czasem jako symbol wyrzutów sumienia Waltera, które on próbuje stłamsić - zabić) oraz antycypujące. I tak różowy miś nie tylko odnosi się do pośredniej winy Waltera za katastrofę, ale ze swoim na wpół zniszczonym pyszczkiem stanowi zapowiedź śmierci jednego z głównych antagonistów bohatera - Gustavo Fringa, który w zamachu bombowym przygotowanym przez Waltera traci pół twarzy. Podobnie rzecz ma się z historią dotyczącą zniszczenia broni zwanej Ciężkim Gustawem, którą Walter opowiada Jessemu - destrukcji potężnego działa dokonał jeden człowiek za pomocą termitu, co czytelnie znów odnosi się do zabicia Fringa przez bohatera. Wszystkie, nawet te najmniejsze, czyny, jakich Walter dokonuje w toku akcji całego serialu, mają swoje, czasem nawet bardzo daleko idące (czyli na zasadzie efektu motyla) konsekwencje. Gdy widząc duszącą się własnymi wymiocinami ukochaną Jessego Jane, nie udziela jej pomocy w nadziei, że jej śmierć pomoże chłopakowi wyjść z narkomanii, sprawia, że pogrążony w rozpaczy ojciec dziewczyny (pracujący jako kontroler ruchu lotniczego) doprowadza do zderzenia dwóch samolotów. Tym samym na Waltera pośrednio spada wina za katastrofę i śmierć setek osób, czego symbolem staje się różowy miś. Skutki poczynań Waltera, który powodowany pychą i chciwością coraz bardziej dąży do zawłaszczenia narkotykowego imperium, dotykają każdą postać w serialu - nawet wtedy, gdy jego działania nie są w nią bezpośrednio wymierzone. Wykłady, które

[15] Ibidem, s. 172-173. 
Walter wygłasza swoim uczniom w liceum, również mają charakter antycypujący wydarzenia. Jego słowa na temat tego, że wszystko w świecie podlega transformacjom oraz że każdy element ma swoją lewą - złą, i prawą - dobrą stronę, przekładają się na proces ewolucji, jakiej on sam będzie poddany - wciąż zmieniający się i odkrywający swe drugie, gorsze oblicze.

Zasada dualizmu natury ludzkiej stanowi kolejną oś, na której oparta jest cała konstrukcja serialu, dlatego też można określić go również dramatem lustrzanych odbić. Nie bez przyczyny Walter przyjmuje dla swego drugiego ja pseudonim Heisenberg - nazwisko uczonego, który jest autorem zasady nieoznaczoności odnoszącej się do niemożności jednoczesnego określenia konkretnych par wielkości. W miarę jak fabuła posuwa się do przodu, a z Waltera stopniowo zaczyna wychodzić bad guy, jego oblicze odbijające się w różnych przedmiotach znajdujących się w kadrze zaczyna się coraz bardziej zniekształcać. $\mathrm{Z}$ początku jest ono symetryczne do rzeczywistego - gdy dowiaduje się o chorobie, widzimy, jak jego postać odbija się w ciemnym blacie stołu lekarskiego (co sugeruje toczącego go raka), a gdy pomaga swojemu choremu synowi ubrać spodnie w szatni, jego odbicie w lustrze jest również klarowne. Goląc głowę przed łazienkowym lustrem, ulega pierwszej transformacji - nie mając bowiem włosów, zaczyna wyglądać jak gangster, co też głośno komentuje jego syn. Z czasem jego lustrzane odbicia stają się coraz bardziej niewyraźne i coraz mniej symetryczne najlepszym tego przykładem jest scena rozgrywająca się $\mathrm{w}$ toalecie kliniki onkologicznej, gdy Walter, niszcząc pięścią blaszany pojemnik na papier do rąk, deformuje ukazujące się na nim oblicze. Gdy kilka epizodów później znów widzimy bohatera w tej samej łazience, jego twarz pojawiająca się na powierzchni zniszczonego urządzenia jest na tyle zamazana, że właściwie nie można jej dostrzec. W jednym z ostatnich odcinków serialu (scena z bohaterem opuszczającym pustynię, na której doszło do morderstwa Hanka) uwagę widza zwraca gest odwrócenia lusterka samochodowego przez Waltera, który nie jest już w stanie utożsamiać się ze swoim drugim - mrocznym i destruktywnym - ja.

Z zasadą symetrii wiąże się następny charakterystyczny dla konstrukcji serialu zabieg, czyli paralelizm. Dotyczy on zarówno postaci samego Waltera, który nieustannie porównywany jest do swoich antagonistów (tak jak Krazy-8 wykrawa skórki z chleba; jak Gus podkłada ręcznik pod kolana, gdy wymiotuje i sam obsługuje klientów w swojej pralni pieniędzy; Hank zbiera minerały-kryształy, a on „gotuje” crystal meth, czyli kryształową metamfetaminę), jak również sytuacji, które zdają się być wobec siebie kompatybilne. Przykład stanowić mogą dwie paralelne wobec siebie sceny - jedna z początku, a druga z końca całego serialu. W pierwszej Walter wkracza do „królestwa” Tuco i za pomocą piorunianu rtęci udaremnia niecne zamiary psychopatycznego dystrybutora „mety”, natomiast w drugiej - podobnie jak na początku bohater na własną rękę przychodzi do mieszkania wroga, czyli w tym 
przypadku grupy nazistów, i pozbywa się ich dzięki skonstruowanemu przez siebie mechanizmowi w postaci automatycznie uruchamiającego się karabinu.

Z pewnością więc spiritus movens całej serii jest Walter-Heisenberg - wciąż ewoluujący i moralnie dwuznaczny bohater, z którym odbiorca się utożsamia i kibicuje jego poczynaniom, a który jednocześnie budzi odrazę ze względu na swe - zawsze tragiczne w skutkach - działania. Tego typu postać, podobnie jak budowanie całej fabuły wokół jej dynamicznie zmieniającej się osobowości i sprzecznego ze społecznie usankcjonowanymi normami postępowania, stała się symptomatyczna dla współczesnych produkcji telewizyjnych. Oprócz charakterystycznych przeskoków czasowych w postaci futuro - i retrospekcji serial posługuje się mnogimi pomniejszymi chwytami świadczącymi o jego narracyjnej złożoności - licznymi przebitkami (gdy Jesse, zabijając zombie w grze komputerowej, widzi obraz martwego Gale'a), teledyskowymi stylizacjami (dynamiczna muzyka, szybki montaż, przyspieszone tempo i zbliżenia towarzyszą często scenom "pichcenia mety”), niekompatybilnością treści obrazu z informacjami niesionymi przez głos zza kadru (Walter mówiący Jessemu, że nie chce uczestniczyć w pertraktacjach $\mathrm{z}$ dilerami a scena, w której mierzy się z Tuco) czy tė̇ odrealnionymi wizjami i marzeniami sennymi wplecionymi w diegezę serialu (narkotykowe halucynacje Jessego).

Breaking Bad wpisuje się zatem w nurt współczesnych telewizyjnych produkcji, które dzięki szeroko wykorzystywanym wachlarzom złożonych zabiegów dążą ku przedefiniowaniu tradycyjnych norm narracyjnych. Forma długiego serialu kontynuowanego umożliwia rozbudowywanie ciągłości fabuły z jednoczesnym zróżnicowaniem epizodów, poszerzanie jej o uzupełniające się wątki i modyfikowanie chronologii przedstawianych wydarzeń za pomocą niekonwencjonalnych rozwiązań dramaturgicznych. Złożoność narracyjna seriali doby telewizji jakościowej pozwala nie tylko na rozwój twórczych strategii, ale także na psychologiczne pogłębienie postaci, poszerzenie aspektów opowiadanej historii oraz rozbudowanie intrygi. Czerpiąc inspiracje $\mathrm{z}$ kina artystycznego, produkcje te nader często wykorzystują charakterystyczne dla niego chwyty, takie jak nietypowe zwroty akcji, wariacje na temat różnorakich motywów czy też nieszablonowy styl opowiadania, nierzadko nawiązujący do tzw. filmów-zagadek ( $p u z z l e$ films). Strategia złożoności narracyjnej zdaje się zatem dominować we współczesnych amerykańskich serialach telewizyjnych. Jak bowiem twierdzi Jason Mittell:

Złożoność narracyjna jest na tyle powszechna i popularna, że okres od lat dziewięćdziesiątych do chwili obecnej możemy uznać za erę telewizyjnej złożoności. [...] [A - przyp. Z.L.] amerykańska telewizja ostatnich 20 lat zostanie zapamiętana właśnie jako okres eksperymentów i innowacji narracyjnych, rzucających wyzwanie możliwościom tego medium[16].

[16] Ibidem, s. 152. 